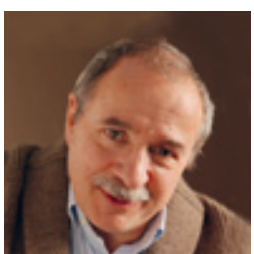

\title{
Vanskelige mennesker?
}

\section{Sliter du med vanskelige pasienter fra tid til annen? Vet du noe om irrite- rende kalkavleiringer på innsiden av kneskålen? Har din tredje meridian vært tett noen gang? Og hva er lik- heten mellom en kvakksalver og en salver?}

Som lærer møter jeg noen forestillinger som er like hardnakkede som de er håpløse. Til dem sogner «den vanskelige eleven». Jeg har gjennom 25 år i yrket ennå til gode å møte den vanskelige eleven. Jeg har møtt elever som ikke klarer å sitte stille, andre som er redde og sinte og høylydte og slike som ikke sier et ord på et helt år. Kryss av for den av de tre som er vanskelig. Ja, det er nettopp det: du får bestemme selv. Vanskelig blir en elev nemlig først idet noen sier at han eller hun er det.

Det tilsvarende i legeyrket må da være «den vanskelige pasienten». Det har jeg kanskje vært selv noen ganger. $D u$ făr dømme.

I mitt livs beskjedne sykejournal figurerer noen nyresteiner. Jeg trodde de var helt konkrete, helt til jeg, på grunn av en rekke omstendigheter, lå på sofaen til en healer. Han klarte å så tvil om den steinharde kjensgjerningen og mente at det neppe var nyresteinen som plaget meg, men heller min tredje meridian, som var tett og som han kunne åpne med sine henders kraft. Altså la han hånd på meg. Han hadde slikt å gjøre, og jeg lot ham gjøre det, uten å forstyrre ham med spørsmål. Den tause håndspåleggelsen varte og rakk, og jeg sovnet. Da både øynene mine og etter alt å dømme også den tilstoppede meridianen var åpne igjen, sa healeren at han skulle skrive ut en medisin som het Katatox og kostet det hvite ut av øyet. Så skulle jeg betale og gå. Jeg betalte, men jeg gikk ikke og ble vanskelig, for nå ville jeg vite mer. Ettersom jeg hadde oppsøkt mannen, godtok jeg selvsagt hans premisser og spurte, liksom fortrolig: - Hvorfor tror du at min tredje meridian er tett? - Det skyldtes en forgiftning. - Jaså, og nå har du altså åpnet den, men hvordan skal jeg forholde meg slik at jeg unngår giften? Skal jeg legge om dietten eller livsmønsteret?

Nei, det var ikke nødvendig, sa min healer. Det holdt visst med avgiftningspillene. Da hoppet jeg av behandlingen og gikk hjem med min ytterst materielle nyrestein, som jeg senere fødte med besvær.

Nå var ikke denne mannen medlem av Legeforeningen, så han er muligens forhåndsdømt på dette papiret. Sannsynlig medlem var derimot hun som jeg mange år tidligere hadde oppsøkt med et vondt kne (etter å ha krøpet rundt på hustaket en hel sommer). Hun kjente litt her og der, spurte om det gjorde vondt og slo fast at det dreide seg om irriterende kalkavleiringer på innsiden av kneskålen, et faktum jeg like godt kunne venne meg til å leve med. Også den gang ble jeg vanskelig og spurte om det ikke var noe jeg kunne gjøre med for eksempel livsstilen eller dietten. Og alt den gangen var svaret en resept, ikke på Katatox men på Paralgin forte, i en mengde som holdt i uoverskuelig fremtid. Jeg sluttet å spørre, gikk derfra og fikk reparert mitt kne fullstendig etter ti behandlinger hos en fysioterapeut.

Legen kan ha tenkt at jeg var en arrogant bedreviter, mens healeren nok anså meg for å være forstokket og utilgjengelig for åndelige realiteter. $\mathrm{Og}$ på neste sammenkomst med yrkeskolleger kan de ha okket seg over denne vanskelige pasienten. Hva vet jeg.

Ordet vanskelig betegner alltid en relasjon og brukes som regel synonymt med «det nytter ikke». Man er ikke vanskelig, men vanskelig i forhold til noe. Hvis en elev ikke sitter stille på plassen sin, da blir det først et problem hvis jeg forventer at han gjør det. Hvis jeg enten forandrer dette kravet eller finner ut årsaken til at han ikke vil (eller kan) sitte stille, da er saken med ett ikke lenger «vanskelig», da kan den løses.

Men da må jeg inkludere eleven, slik en lege må inkludere pasienten, se og involvere henne eller ham. I mine to eksempler er det derfor lite som skiller kvakksalveren fra salveren. En homøopat jeg kjenner sa engang, blottet for selvhøytidelighet: Min jobb består i å lytte til mennesker, jeg tar meg tid til det. Ofte er det ikke mer de trenger for å bli friske.

Det er ikke så vanskelig.

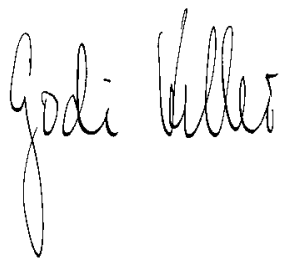

\section{I neste nummer:}

Tema: Søvn

\section{Svineinfluensa}

Antihypertensiver og glukosemetabolisme
MedHum 2009

Tiltalt og syk

EU-lov om legemidler til barn 